Article

\title{
Built Environment Features and Pedestrian Accidents: An Italian Retrospective Study
}

\author{
Tanja Congiu ${ }^{1}$, Giovanni Sotgiu ${ }^{2, *(1)}$, Paolo Castiglia ${ }^{2}$, Antonio Azara ${ }^{2}$, Andrea Piana ${ }^{2}$, \\ Laura Saderi $^{2}$ (i) and Marco Dettori ${ }^{2}$ (1) \\ 1 Department of Architecture, Design and Urban Planning, University of Sassari, 07100 Sassari, Italy; \\ tancon@uniss.it \\ 2 Department of Medical, Surgical and Experimental Sciences, University of Sassari, 07100 Sassari, Italy; \\ castigli@uniss.it (P.C.); azara@uniss.it (A.A.); piana@uniss.it (A.P.); lsaderi@uniss.it (L.S.); \\ madettori@uniss.it (M.D.) \\ * Correspondence: gsotgiu@uniss.it; Tel.: +39-079-229-959
}

Received: 8 January 2019; Accepted: 14 February 2019; Published: 18 February 2019

\begin{abstract}
Daily walking is a recommended physical activity. It can be an all-age suitable, environment-friendly transport option. However, traffic crashes are a widely recognized risk factor, associated with drivers' errors or a combination of several environmental factors, including physical characteristics of the road space. The aim of this study was to assess the characteristics of built environments on pedestrian safety. Data on road accidents that had occurred between 2005 and 2015, in Alghero, Italy, were retrieved and matched with spatial and functional street qualities. On-street parking was found to increase the risk of pedestrian accidents by about two times, whereas, narrow travel lanes and intersections reduced the incidence of crashes and their public relevance. These field results could inform urban health and spatial planning policies with the final goal of improving health and providing more sustainable models of urban organization.
\end{abstract}

Keywords: active transport; urban health; pedestrian accidents; road accidents; Italy

\section{Introduction}

Physical harassment and road traffic accidents have been recognized by the World Health Organization as the main health threats in urban settings, along with communicable and non-communicable diseases [1]. Traffic accidents can involve several individuals, including pedestrians. As a consequence of this, citizens avoid routine walking. In particular, this preventative behavior can be frequently detected in vulnerable population groups (e.g., elderly, children, or disabled persons). In Europe $\sim 21 \%$ of all traffic-related fatalities involve pedestrians, mainly elderly people and children. Of all pedestrian fatalities, $69 \%$ are found to have occurred in urban areas, where vehicular speed was found to have been the key, in $\sim 30 \%$ of cases [2].

The improvement of pedestrian safety in the urban environment could support a more active lifestyle, leading to the decrease of incidence and mortality associated with chronic disorders [3-15].

Qualities of the roadscape, such as the directness, continuity, distance, visibility, pleasantness, sense of enclosure and safety, encourage pedestrians to walk [16-18]. Walking is a free, low-impact activity, and also the most environmentally sustainable mode of transport $[19,20]$.

Walking-friendly policy measures and spatial interventions (e.g., initiatives aiming at reducing the use of private car and promoting non-motorized modes of transports, traffic restrictions, pedestrian friendly facilities, traffic calming measures, redesign of streets, etc.) can reduce the risk of pedestrian accidents [21-23]. Vehicular traffic is recognized as the major risk factor [24], followed by the street layout [25-27]. The influence of road network patterns on safety was recently explored by Guo et 
al. [28] who found the grid pattern network to be the least safe, compared to the irregular street layout, due to its inherent high level of integrations and connectivity, and consequently, higher potential for pedestrian-vehicle conflict points. The influence of road network structure on traffic volumes and vehicular speed has been widely demonstrated [29-31]. Likewise, pedestrian behavior and route choice are also affected by urban design qualities, such as attractiveness (mixed land use) aesthetic and comfort of the streetscape [32,33]. In their studies on childhood accidents, Kadali and Vedagiri [34] and Nasar et al. [35] observed that parents who let their children walk to school by themselves, take into consideration traffic volume (i.e., hour rate of cars), vehicular speed, and physical barriers between cars and pedestrians.

Determinants of pedestrian-vehicle accidents are studied by several scientific fields, from transport to epidemiology to urban health studies. In a recent work, built environment (BE) and road design characteristics have been carefully evaluated through a multi-disciplinary approach [36,37]. $\mathrm{BE}$ is represented by the following characteristics-physical attributes of the road network and its nearby surroundings (cross-section geometry, speed limits, on-street activities, parked cars, green areas, and view) measured at the street level, for the whole urban network.

The relationship between BE characteristics, traffic accidents, and their related severity has been assessed in different settings, using different research methods; in particular, descriptive and inference statistics, in combination with spatial analysis have been frequently adopted to provide a comprehensive overview of the potential causal relationships. Traffic safety determinants have also been investigated frequently using regression models. Table 1 shows relevant studies conducted on this topic, in the last decades.

Table 1. Built environment characteristics, methods, and potential factors responsible for accidents.

\begin{tabular}{|c|c|c|c|c|c|}
\hline \multirow{2}{*}{ Study } & \multirow{2}{*}{ Location of Study } & \multirow[b]{2}{*}{ Method } & \multicolumn{2}{|c|}{ Built Environment } & \multirow{2}{*}{$\begin{array}{l}\text { Principal Influence Factor of } \\
\text { Vehicle-Pedestrian Accident } \\
\text { Occurrence/Severity }\end{array}$} \\
\hline & & & $\begin{array}{l}\text { Spatial Unit of } \\
\text { Analysis }\end{array}$ & Features & \\
\hline \multirow{8}{*}{ Wier, 2009 [38] } & \multirow{8}{*}{$\begin{array}{l}\text { San Francisco } \\
\text { (USA) }\end{array}$} & \multirow{8}{*}{$\begin{array}{l}\text { Multivariate area-level } \\
\text { regression model (ordinary } \\
\text { least squares regression) }\end{array}$} & \multirow{8}{*}{ Census tract } & Traffic volume & Traffic volume \\
\hline & & & & Street functional class & Arterial streets without public transit \\
\hline & & & & Intersections & \\
\hline & & & & Street length & \\
\hline & & & & Land Use & $\begin{array}{l}\text { Commercial use and residential-commercial } \\
\text { use land area }\end{array}$ \\
\hline & & & & Demographic data & Proportion of people aged 65 and over \\
\hline & & & & Socio-economic data & $\begin{array}{l}\text { Employee and resident populations, } \\
\text { proportion of people living in poverty }\end{array}$ \\
\hline & & & & $\begin{array}{l}\text { Commuters Travel } \\
\text { behavior }\end{array}$ & \\
\hline \multirow{5}{*}{$\begin{array}{l}\text { Dumbaugh, } \\
2011[39]\end{array}$} & \multirow{5}{*}{$\begin{array}{l}\text { San Antonio-Bexar } \\
\text { County (USA) }\end{array}$} & \multirow{5}{*}{$\begin{array}{l}\text { Regression models: Negative } \\
\text { binomial }\end{array}$} & \multirow{5}{*}{ Census block } & $\begin{array}{l}\text { Land use: Commercial } \\
\text { strip, big box stores, } \\
\text { pedestrian-scaled retail } \\
\text { uses }\end{array}$ & Pedestrian-scaled retail uses \\
\hline & & & & $\begin{array}{l}\text { Intersection number and } \\
\text { type }\end{array}$ & Intersections \\
\hline & & & & $\begin{array}{l}\text { Street network: Freeway } \\
\text { and arterial mileage, } \\
\text { surface arterial mileage }\end{array}$ & Vehicle speed \\
\hline & & & & $\begin{array}{l}\text { Traffic volumes: Vehicle } \\
\text { miles of travel }\end{array}$ & \\
\hline & & & & $\begin{array}{l}\text { Demographic: Net } \\
\text { population density }\end{array}$ & \\
\hline \multirow{7}{*}{$\begin{array}{l}\text { Ukkusuri, } \\
2011[40]\end{array}$} & \multirow{7}{*}{$\begin{array}{l}\text { Ney York } \\
\text { City (USA) }\end{array}$} & \multirow{7}{*}{$\begin{array}{l}\text { Regression models: Negative } \\
\text { binomial; negative binomial } \\
\text { with heterogeneity in } \\
\text { dispersion parameter; } \\
\text { zero-inflated } \\
\text { negative binomial }\end{array}$} & \multirow{7}{*}{$\begin{array}{l}\text { Census tract } \\
\text { and zip code }\end{array}$} & $\begin{array}{l}\text { Land-use composition } \\
\text { (activities along the street) }\end{array}$ & Land-use types, number of schools \\
\hline & & & & Intersection density & \\
\hline & & & & Road functional class & \\
\hline & & & & Road density & \\
\hline & & & & $\begin{array}{l}\text { Road geometry (length, } \\
\text { width, lanes) }\end{array}$ & Number of lanes and road width \\
\hline & & & & Transit supply & Number of transit stops \\
\hline & & & & $\begin{array}{l}\text { Demographic } \\
\text { characteristics }\end{array}$ & \\
\hline
\end{tabular}


Table 1. Cont.

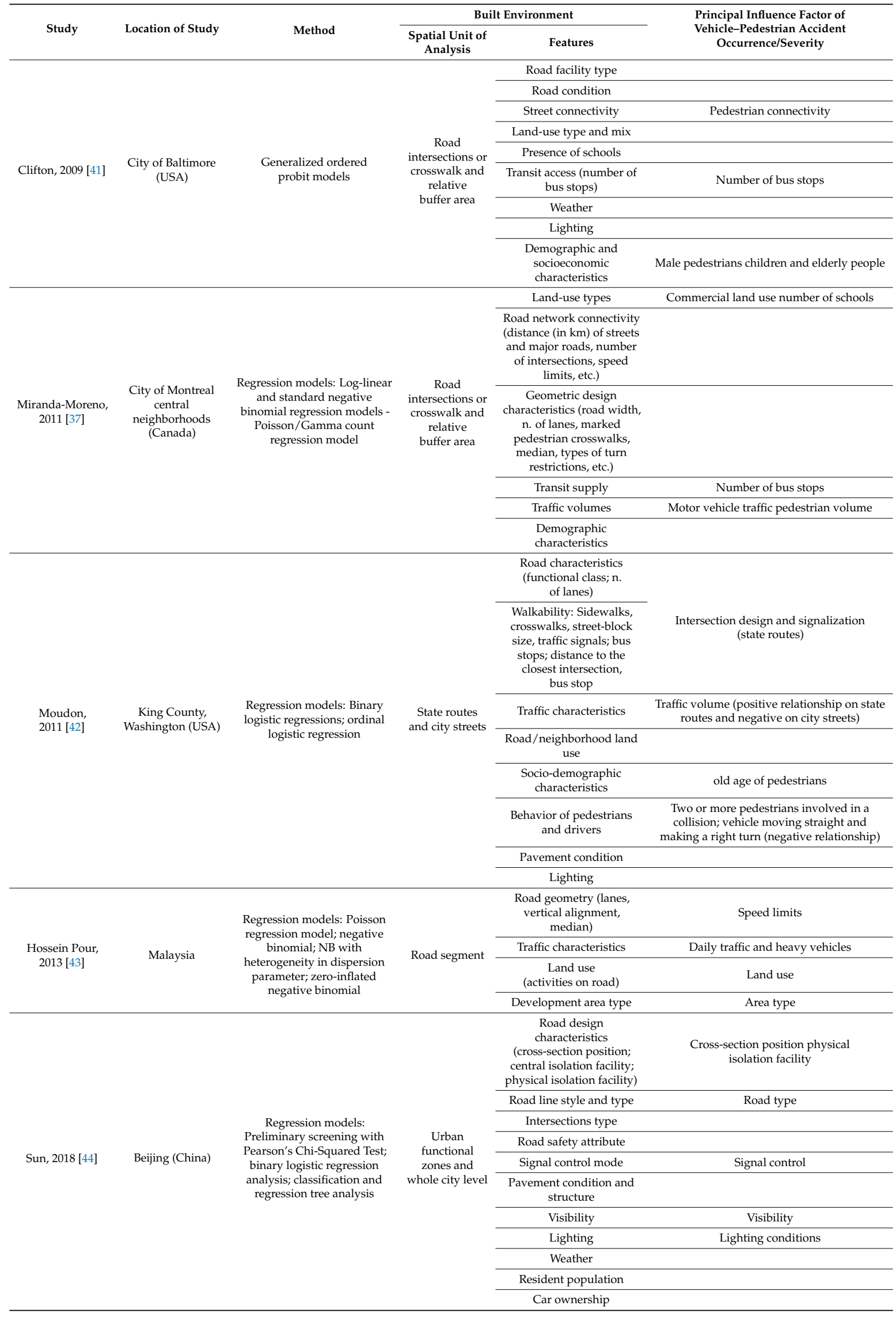


With regards to the above, aim of the present study was to assess the relationship between physical characteristics of BE and pedestrian accidents in a high-income country located in the European Union.

In particular, we carried out a study to evaluate the relationship between vehicle-pedestrian accidents in the urban area of Alghero (Italy) and the characteristics of BE.

We detailed a fine-grain level, aimed at providing a high resolution and a significant data variability, which are key to build a robust model of pedestrian's accident risk. Indeed, micro-scale $\mathrm{BE}$ data allows for a more disaggregate analyses of the data and ensures more variation within the variables [41].

Findings of the study can be informative for traffic engineers, urban planners, and police officers to address the issue of safe mobility and can represent the evidence of new policies.

\section{Materials and Methods}

\subsection{Study Setting}

An observational retrospective study was carried out between 1st January 2005 and 31st December 2015 in Alghero, Italy.

Alghero, a city located in the north-western area of Sardinia, Italy, had an average population of 42,170 inhabitants, during the study period.

The database of the local police, which included place, day, and hour of the accidents, as well as days of prognosis was used to retrieve information on pedestrian accidents. Characteristics of the built environment were collected using Google Street View and direct visual inspections.

\subsection{Built Environment Characteristics}

Following a literature review we listed key environmental factors affecting walking behavior. The urban form characteristics considered, encompassed the geometric, functional, and design features of the street network and its surrounding environment, which act as determinants of the road quality.

For this purpose, each segment of the Alghero street network was described by seventeen predetermined built environment attributes, collected during previous studies on Alghero's walkability $[45,46]$. During the period 2005-2015, no substantial changes were carried out on street networks. Thus, the main environmental features were unchanged.

Street attributes were-number of lanes and directions; cycle lanes and their position in relation to carriageway; car speed limit; on-street parking; sidewalk width; paving quality; street lights; and the path slope. Other built environment qualities affecting walking $[47,48]$ included, transparency and permeability of urban space, which concerns the relationship between the pedestrian and the surrounding environment [49]; repair, which refers to the presence of shelters from rain, wind, or sun, along the street; frequency of services and activities along the path, which refer to Jane Jacobs' "eyes on the city" concept and the related perception of the street as a safe and practiced environment, due to the presence of people and urban facilities [50]; urban texture, which accounts for building density and typology [17], ranging from dense continuous to scattered urban fabric and undeveloped land.

\subsection{Geographic Information System (GIS) Analysis}

Accidents were examined and mapped using geographic information systems. We used QGIS (https:/ / www.qgis.org) to geo-reference data based on the street address provided in the dataset.

To represent the density of accidents over space, we used the SANET [51] software tool, coupled with ARCGIS 10 (http://sanet.csis.u-tokyo.ac.jp/sub_en/programV4.html), which estimates the density of traffic accidents on the road network (NKDE) and detects the locations where the densities of these occurrences are high (black zones).

SANET resorts to a kernel density estimation method [52], which applies the equal-split continuous kernel density function to the distribution of road accidents. The resulting NKDE corresponds to the number of accidents per meter of road segment. More precisely, crashes within the 
kernels are weighted based on their network distance from the kernel center, measured along the street network, by an unbiased kernel function. One important parameter to set, the bandwidth, was fixed at $100 \mathrm{~m}$ in this study, as per the results obtained from previous studies [51,53]; it is the most common value used to model pedestrian catchment areas at a block or street level (generally comprised within 100-300 m) [54-56].

NKDE is a method extensively adopted in the analysis of traffic accidents-it provides more precision in the location of crashes, being exclusively assigned to the road network, and, thus, limiting over-detection during the density estimation.

The estimation of the density of crashes occurring along the road network can help identify black zones and, thus, help implement preventive interventions, based on the removal of prevalent spatial and environmental factors associated with pedestrian accidents.

\subsection{Statistical Analysis}

An ad hoc electronic form was prepared using Excel (Microsoft Office). Qualitative and normally-distributed quantitative variables were summarized with absolute (relative) frequencies and means (standard deviations (SD)), respectively. As in previous studies (Table 1) that have investigated the relationships between urban environment features and road accidents, a logistic regression analysis was performed to assess the relationship between the occurrence of pedestrian accidents and the above-mentioned variables. It provided quantitative estimates (Odds Ratios (OR)) on the relationship between the outcome variables and independent variables (multivariate model), chosen on the basis of the published scientific evidence and on their statistical significance in the univariate model. A two-tailed $p$-value less than 0.05 was considered statistically significant. Statistical computations were performed using STATA 15 (StataCorp, Texas).

\section{Results}

Between 1st January 2005 and 31st December 2015, 1,283 road accidents were reported by the local Police of Alghero.

Spatial representation of the accidents showed that an equal distribution of crashes occurred at midblock locations (50.5\%) and intersections (49.5\%) (Figure 1). Pedestrian accidents were 97 $(7.6 \%)$, whereas $52(4.1 \%)$ involved cyclists, and 1,134 (88.3\%) were accidents only involving vehicles. In particular, 41 of the 97 (42.3\%) pedestrian accidents were mild ( $<20$ days of prognosis), $54(55.7 \%)$ were serious ( $\geq 20$ days of prognosis), and $2(2.1 \%)$ were fatal.

The overlay of the network kernel density estimation of accidents (Figure 1c) and the GIS maps of Alghero, containing key socio-spatial information about the urban areas, show that most crashes occurred in locations characterized by a high-density of population, services, and activities.

All $(100 \%)$ urban roads, accounting for $>175$ kilometers of streets, were examined with respect to the 17 variables related to the built-environment. Urban roads were divided into 1376 edges of different length (median (Interquartile Range -IQR) = 92.5 meter (64.5-116.15)). Each road of the graph was split into edges, based on 17 variables-every time a single quality changed, the edge was broken. Descriptive data of built environment characteristics are shown in Table 2. 


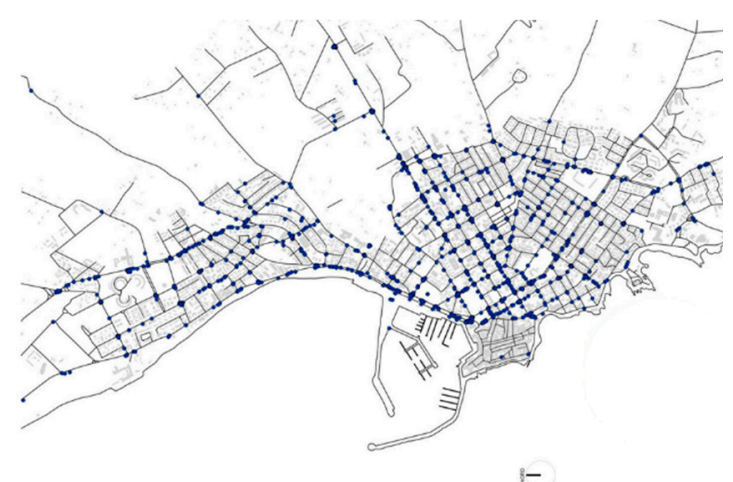

(a)

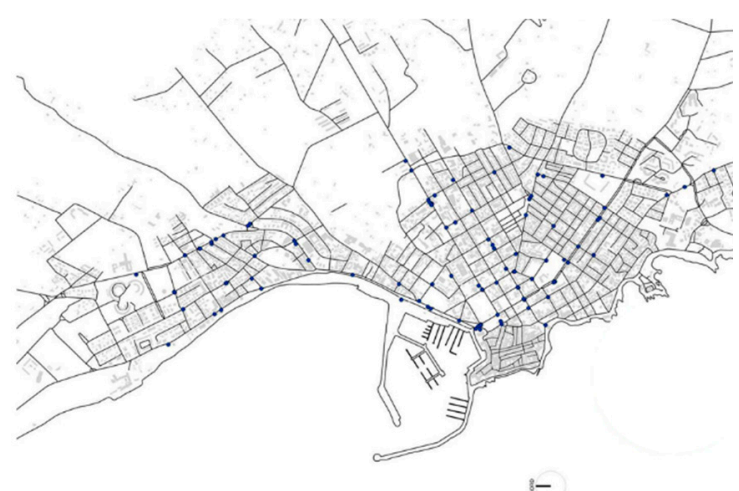

(b)

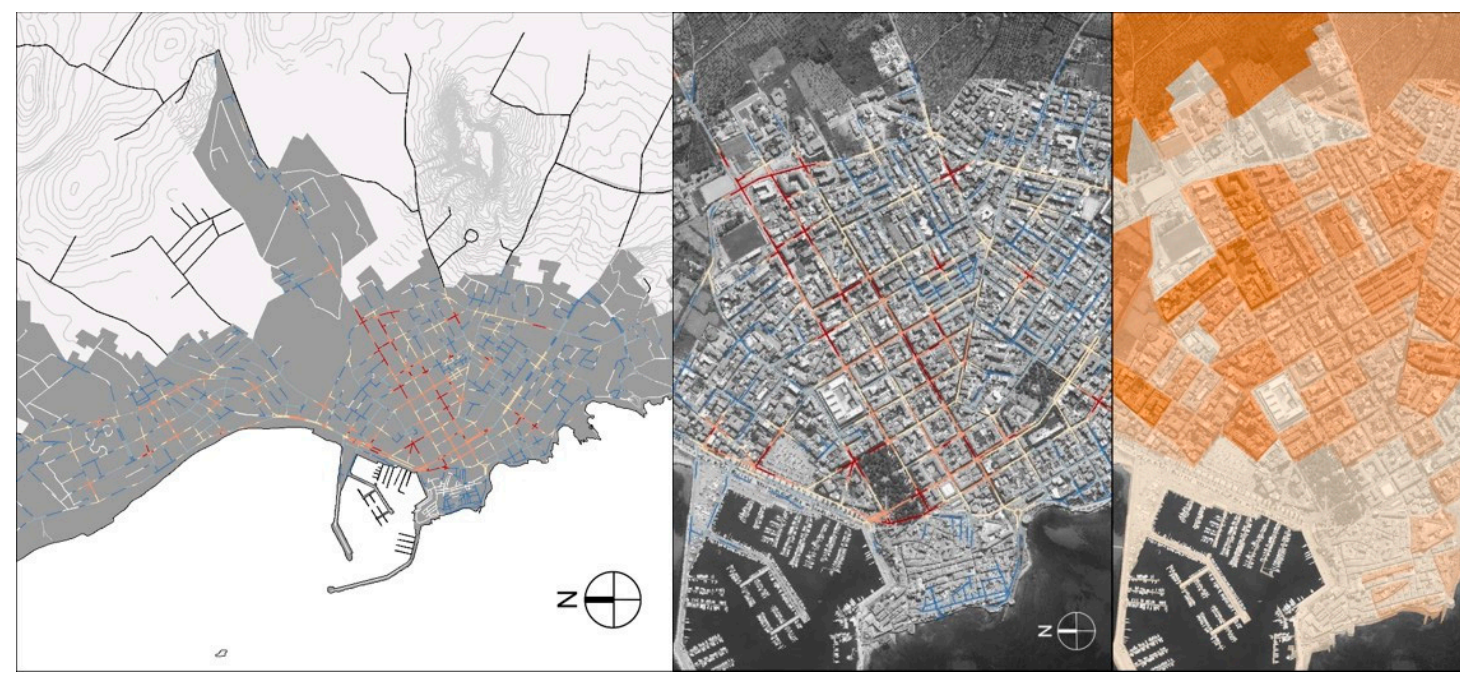

(C)

Figure 1. Location of the accidents that occurred in the urban area of Alghero, between 2005 and 2015. (a) Geolocation of all 1,283 accidents observed. (b) Pedestrian accidents location. (c) Kernel density estimation calculated on the road network.

Table 2. Urban characteristics of streets, in Alghero, Italy. Number (in percentage) of each environmental variable collected.

\begin{tabular}{|c|c|c|}
\hline Environmental Variables & & No. $(\%)$ \\
\hline \multirow{2}{*}{ Street lighting } & Yes & $1114 / 1376(81.0)$ \\
\hline & No & $262 / 1376(19.0)$ \\
\hline \multirow{5}{*}{ Speed limit } & Pedestrian way & $85 / 1376(6.2)$ \\
\hline & $20 \mathrm{Km} / \mathrm{h}$ & $13 / 1376(0.9)$ \\
\hline & $30 \mathrm{Km} / \mathrm{h}$ & $299 / 1376(21.7)$ \\
\hline & $50 \mathrm{Km} / \mathrm{h}$ & $959 / 1376(69.7)$ \\
\hline & $70 \mathrm{Km} / \mathrm{h}$ & 20/1376 (1.5) \\
\hline \multirow{2}{*}{ Pedestrian shelter } & Yes & $553 / 1376(40.2)$ \\
\hline & No & $823 / 1376(59.8)$ \\
\hline \multirow{2}{*}{ On-street parking } & Yes & $962 / 1376(69.9)$ \\
\hline & No & $414 / 1376(30.1)$ \\
\hline
\end{tabular}


Table 2. Cont

\begin{tabular}{|c|c|c|}
\hline Environmental Variables & & No. $(\%)$ \\
\hline \multirow{2}{*}{ Paving quality and degree of maintenance } & Fine & $116 / 1376(8.4)$ \\
\hline & Bumpy & $1260 / 1376(91.6)$ \\
\hline \multirow{4}{*}{ Width of sidewalk } & Wide ( $\geq$ 3persons side by side) & $223 / 1376(16.2)$ \\
\hline & Comfortable ( 2 persons can walk side by side) & $107 / 1376(7.8)$ \\
\hline & Minimum ( 1 one person can walk) & $600 / 1376(43.6)$ \\
\hline & None (no sidewalk along the street) & $446 / 1376(32.4)$ \\
\hline \multirow{4}{*}{ Street lanes number } & 0 (pedestrian street) & $77 / 1152(6.7)$ \\
\hline & 1 & $426 / 1152(37.0)$ \\
\hline & 2 & $645 / 1152(56.0)$ \\
\hline & 3 & $4 / 1152(0.3)$ \\
\hline \multirow{2}{*}{ Pedestrian/driveway separation } & Yes & $399 / 1376(29.0)$ \\
\hline & No & $977 / 1376(71.0)$ \\
\hline \multirow{3}{*}{ Path Slope } & Flat & $82 / 1376(6.0)$ \\
\hline & Slight & $712 / 1376(51.7)$ \\
\hline & Ascent & $582 / 1376(42.3)$ \\
\hline \multirow{3}{*}{ One-way street } & Pedestrian path & $65 / 1376(4.7)$ \\
\hline & Yes & $503 / 1376(36.6)$ \\
\hline & No & $808 / 1376(58.7)$ \\
\hline \multirow{3}{*}{ Bicycle lane } & Separated (for bikes only) & $72 / 1376(5.2)$ \\
\hline & Shared use path (bikes and pedestrians) & $161 / 1376(11.7)$ \\
\hline & Shared in-roadway bikeways (bikes and vehicles) & $1143 / 1376(83.1)$ \\
\hline \multirow{2}{*}{ Activities and services } & Yes & $781 / 1375(56.8)$ \\
\hline & No & $594 / 1375(43.2)$ \\
\hline \multirow{2}{*}{ Opportunity to sit } & Yes & $286 / 1375(20.8)$ \\
\hline & No & $1089 / 1375(79.2)$ \\
\hline \multirow{3}{*}{ Historical-Architectural-Urban interest } & Presence of pleasant elements & $220 / 1375(16.0)$ \\
\hline & Absence of pleasant or disturbance elements & $1125 / 1375(81.8)$ \\
\hline & Presence of a disturbance elements & $30 / 1375(2.2)$ \\
\hline \multirow{3}{*}{ Environmental interest } & Presence of pleasant elements & $564 / 1375(41.0$ \\
\hline & Absence of pleasant or disturbance elements & $809 / 1375(58.9)$ \\
\hline & Presence of disturbance elements & $2 / 1375(0.1)$ \\
\hline \multirow{3}{*}{ Public-private space buffer } & Permeable & $643 / 1375(46.8)$ \\
\hline & Filtered & $502 / 1375(36.5)$ \\
\hline & Separated & $230 / 1375(16.7)$ \\
\hline \multirow{4}{*}{ Urban fabric } & Dense on both sides & $813 / 1375(59.1)$ \\
\hline & Low density on both sides & $334 / 1375(24.3)$ \\
\hline & Park or green space & $71 / 1375(5.2)$ \\
\hline & Undeveloped area & $157 / 1375(11.4)$ \\
\hline
\end{tabular}

The majority of the streets had a minimal slope (51.7\%) and showed a lighting system (presence of street lamps), whereas pedestrian shelters were rare (they were lacking, in $59.8 \%$ of cases), and sidewalk width were inadequate (excessively small and missing in $43.6 \%$ and $32.4 \%$ of the cases, respectively). The opportunity for pedestrians to be seated was $59.8 \%$, sidewalks were built using cheap pavement materials (i.e., bitumen), and the pavements were often bumpy. 
The majority of the urban roads had $50 \mathrm{~km} / \mathrm{h}$ speed limit $(69.7 \%)$, two lanes $(56.0 \%)$, and authorized on-street parking (58.7\%). There was no relevant separation of pedestrian path from driveway area, in more than seventy percent of the streets $(71.0 \%)$, and the view of environmental and historical-architectural interest elements was limited to a few paths.

About $59.1 \%$ of the street segments walked over a dense and symmetric urban fabric, with blocks directly opening onto the street $(46.8 \%$ ) or being separated by semi-private or private spaces (fences, front yards, and porches). Single-use areas (residential) were more frequent, being for commercial activities or urban services, and were completely missing in $43.2 \%$ of streets. Bicycle lanes shared the roadway with the vehicular traffic in the majority $(83.1 \%)$ of the urban street-edges. Table 3 shows the results of the logistic regression analysis.

Table 3. Logistic regression analysis to investigate the relationship between pedestrian accidents and urban characteristics. Univariate and multivariate analysis evaluated the association between pedestrian accident occurrences and independent environmental variables.

\begin{tabular}{ccccc}
\hline \multirow{2}{*}{ Urban Characteristics } & \multicolumn{2}{c}{ Univariate Analysis } & \multicolumn{2}{c}{ Multivariate Analysis } \\
\cline { 2 - 5 } & OR (95\% CI) & $p$-Value & OR (95\% CI) & $p$-Value \\
\hline Pedestrian shelter & $0.8(0.6-1.2)$ & 0.276 & - & - \\
On-street parking & $2.1(1.3-3.5)$ & 0.005 & $1.8(1.1-3.2)$ & 0.025 \\
Street lanes number & $1.4(1.0-1.9)$ & 0.035 & $1.6(1.1-2.1)$ & 0.005 \\
Pedestrian/driveway separation & $6.0(2.3-13.7)$ & 0.000 & $6.9(2.7-13.4)$ & 0.000 \\
One-way street & $1.2(0.9-1.7)$ & 0.257 & - & - \\
Opportunity to sit & $1.6(1.1-2.2)$ & 0.016 & $0.7(0.5-1.1)$ & 0.118 \\
Street length & $1.0(0.9-1.0)$ & 0.014 & $1.0(0.99-1.0)$ & 0.229 \\
Intersections & $0.7(0.5-1.0)$ & 0.034 & $0.6(0.0-0.0)$ & 0.009 \\
\hline
\end{tabular}

A total of 17 independent variables were included in univariate models to assess their intensity of association with the pedestrian accident occurrence. Nine variables showed collinearity, whereas, eight showed a statistically significant relationship with the outcome variable, and were included in the multivariate analysis.

The multivariate analysis showed that some environmental conditions resulted in a significant association with the occurrence of pedestrian accidents. Accordingly, on-street parking, road lane number, and separation between pedestrian and driveway areas were associated with an increased risk of pedestrian accidents. Conversely, road intersections could decrease the risk of accidents.

\section{Discussion}

Association between urban form, increased physical activity, and health benefits has been clearly proved $[57,58]$. The present study evaluated the relationship between built environment characteristics and pedestrian accidents, with the goal of providing elements to improve pedestrian safety and, then, to encourage walking and promote a healthy lifestyle. To the best of our knowledge this is the first study describing the relationship between built environment characteristics and pedestrian accidents in Sardinia. The results of the present study confirmed the findings showed in other geographical contexts-some urban characteristics, such as road lane number and the presence of a buffer space between pedestrians and vehicular traffic, were associated with an increased risk of pedestrian injury. It was widely demonstrated that a greater number of lanes and wider road lanes could favor an increased vehicle speed [59-61] and, consequently, a higher risk of serious pedestrian injuries. According to Dumbaugh and Li [39], high vehicular speed and conflicts between vehicles and pedestrians are two systematic, urban, design-related problems, which can influence the incidence and severity of accidents. Likewise, vehicle speed increases the risk of accidents, resulting in the drivers having inadequate time to react to unexpected hazards. Higher vehicular speed results in an increased occurrence and severity of crashes involving pedestrians, and it mainly affects arterial roads, showing the ineffectiveness of "forgiving design elements", i.e., wide lanes and traffic islands [33,62]. 
Conversely, according to Schuurman et al. [63] and Stoker et al. [64], pedestrian-oriented environments, based on the coexistence of motorized and non-motorized traffic (e.g., walkable and livable streets with retail activities on roadside, aesthetic streetscape, and traffic calming measures or sharing spaces) contribute to the incidence reduction of urban crashes.

Our study found that separation between pedestrian and vehicle areas increased the risk of pedestrian accidents - a two-fold risk of pedestrian accident was found when there were parked cars along the carriageway, whereas, it was seven-fold higher in case of physical elements separating walkways from vehicles. These findings could be explained by the obstruction of the mutual visibility of pedestrians and cars as a result of physical elements and urban equipment, frequently located in the spaces next to the sidewalk. Such obstacles ranged from vertical items (poles, standpipes, road and commercial signages, and rubbish containers) to linear strips acting as transition zones between the sidewalk and the roadway, used as parking, public transport passenger loading zone, planting trees or vegetation, holding street furniture (benches, cycle racks, bins, etc.). Although these elements minimized the sidewalk car intrusion and contributed to the improvement of the streetscape quality [65], they also hindered the roadside, decreasing pedestrian view while crossing the streets $[27,66]$. This obstructing effect occurs mainly when on-street parking is planned. Several studies $[39,49,67,68]$ have confirmed that parked cars are associated with crashes, obstructing the visibility of the pedestrians crossing the streets (e.g., children). The relocation of parking lots to the sidewalks can be a feasible solution, ensuring more safety and comfort for road users. The pedestrian-parking risk is low due to the low-speed during parking, due to the interference between traffic and parking cars. A 50-80 cm empty strip along the kerb is needed to ensure the visibility of pedestrians crossing the street, who are otherwise masked by parked cars. This solution requires the availability of space in the road cross-sections, part of which can be recovered by narrowing the carriageway, which are often too wide in some urban arterials.

Another interesting finding is the decreased risk of pedestrian accidents at road intersections. This result emphasizes that both pedestrian and drivers pay more attention while approaching the street nodes.

Relocation of parking lots, extension of low speed limits (i.e., $30 \mathrm{~km} / \mathrm{h}$ ) to all urban areas, and reduction of the carriageway width, including removable elements (planters, roadblocks, cones, etc.), are easy-to-adopt measures. Recent approaches of urban regeneration rely on rethinking the street layout - which has resulted in a significant improvement in pedestrian safety, public space quality, and usability, by resorting to micro design interventions [69-71]. The Street Plans project for Jersey City (USA), which included temporary curb extensions in some urban corridors that were unsafe for pedestrians, is a classic example. Designers planned short-term and low-cost actions (colorful paint, wayfinding signage, planters, tables and chairs, using a budget $<2,000 \$$ ), aimed at improving the safety of the living environment [72].

Another important action would be the implementation of integrated strategies, based on complementary land use and transport policies, improving injury prevention and urban health. Improvement of walking and cycling facilities, streetscape renovation, as well as educational programs and media campaigns could favor a more responsible driving and walking behavior, by supporting healthy lifestyles.

As highlighted by Finch and Hayen [73], "the establishment of strategic and effective partnerships between public health and other government agencies can lead to a) co-own the injury problem, (b) develop, trial, and implement identified solutions; and (c) widely disseminate and implement those solutions outside of the health sector".

Pedestrian safety should be a shared responsibility of the stakeholders who play a role in the planning system, including politicians, planners, health agencies, police, community organizations, transport service companies and organizations, and road users. On this basis, the "Vision Zero" policy founded in Sweden in the late 1990s and implemented in several European and North America settings, has been an innovative strategy for road safety [74]. Vision Zero proved to be effective, both, in the 
prevention of traffic accidents and in the definition of evidence-based solutions for promoting health and wellbeing to such an extent that one of the latest UN plans of actions for the Decade of Action [75] was inspired by the Sweden policy.

The following limitations can hinder the reliability of our findings—-dataset of accidents included only information on vehicular versus pedestrian crashes. Information on pedestrian accidents occurred in circumstances other than traffic crashes were not available (e.g., those caused by poor quality of and endurance of street materials, or those associated with neglected maintenance of walkways), as well as information about the dynamics of accident occurrence (i.e., driver or pedestrian faults). This drawback was a consequence of the data source we chose, as the local police collects data only on urban traffic collisions.

Moreover, detailed information on accident dynamics are missing, as there are no information on the role played by pedestrians. A literature review highlighted how personal characteristics, attitudes, and habits (e.g., age, cognitive abilities, distraction, lack of caution, use of cell phones) can increase the risk of pedestrian accidents [76-78]. Hence, the inclusion of the above-mentioned factors in a new dataset will help to improve our study findings.

\section{Conclusions}

The assessment of the relationship between BE characteristics and pedestrian accidents is useful for planners, decision makers, and road users. This approach can help detect issues and their causes, plan actions and priorities, as well as increase awareness of the value of health. A detailed evaluation of the factors contributing to traffic accidents, mainly spatial characteristics, is key to design and implement effective countermeasures.

Our Italian study confirmed outcomes of previous studies conducted in other geographic areas. Similar studies in other Sardinian towns could provide new findings and identify potential confounding factors. The results of the study can inform urban policies and interventions oriented to the improvement of safety and quality of pedestrian areas, promoting a non-motorized mode of transport and, consequently, active lifestyles. In particular, we endorse a pedestrian-oriented approach to be adopted in urban transport planning and road design.

Author Contributions: Conceptualization, T.C., G.S., P.C., and M.D.; Data curation, T.C., G.S., A.A., A.P., L.S., and M.D.; Formal analysis, T.C., G.S., L.S., and M.D.; Funding acquisition, P.C.; Investigation, T.C., A.A., A.P., and M.D.; Methodology, G.S. and P.C.; Supervision, G.S.; Writing—original draft, T.C., P.C., A.A., A.P., and M.D.; Writing-review and editing, T.C., G.S. and M.D.

Funding: This research received no external funding.

Conflicts of Interest: The authors declare no conflict of interest.

\section{References}

1. World Health Organisation. Urban Health. Available online: http://www.who.int/topics/urban_health/en/ (accessed on 7 January 2019).

2. Levulytė, L.; Baranyai, D.; Sokolovskij, E.; Török, Á. Pedestrian's role in road accidents. Int. J. Traffic Transp. Eng. 2017, 7, 328-341.

3. Hovell, M.F.; Sallis, J.F.; Hofstetter, C.R.; Spry, V.M.; Faucher, P.; Caspersen, C.J. Identifying correlates of walking for exercise: An epidemiologic prerequisite for physical activity promotion. Prev. Med. 1989, 18, 856-866. [CrossRef]

4. Ballor, L.D.; Keesey, R. A meta-analysis of the factors affecting exercise-induced changes in body mass, fat mass and fat-free mass in males and females. Int. J. Obes. 1991, 15, 717-726. [PubMed]

5. Siegel, P.Z.; Brackbill, R.M.; Heath, G.W. The epidemiology of walking for exercise: Implications for promoting activity among sedentary groups. Am. J. Public Health 1995, 85, 706-710. [CrossRef] [PubMed]

6. Phillips, W.T.; Pruitt, L.A.; King, A.C. Lifestyle Activity. Sport. Med. 1996, 22, 1-7. [CrossRef] 
7. Hakim, A.A.; Petrovitch, H.; Burchfiel, C.M.; Ross, G.W.; Rodriguez, B.L.; White, L.R.; Yano, K.; Curb, J.D.; Abbott, R.D. Effects of Walking on Mortality among Nonsmoking Retired Men. N. Engl. J. Med. 1998, 338, 94-99. [CrossRef]

8. Dunn, A.L.; Marcus, B.H.; Kampert, J.B.; Garcia, M.E.; Kohl, H.W.; Blair, S.N. Comparison of lifestyle and structured interventions to increase physical activity and cardiorespiratory fitness: A randomized trial. J. Am. Med. Assoc. 1999. [CrossRef]

9. Manson, J.E.; Hu, F.B.; Rich-Edwards, J.W.; Colditz, G.A.; Stampfer, M.J.; Willett, W.C.; Speizer, F.E.; Hennekens, C.H. A Prospective Study of Walking as Compared with Vigorous Exercise in the Prevention of Coronary Heart Disease in Women. N. Engl. J. Med. 1999, 341, 650-658. [CrossRef]

10. Brownson, R.C.; Housemann, R.A.; Brown, D.R.; Jackson-Thompson, J.; King, A.C.; Malone, B.R.; Sallis, J.F. Promoting physical activity in rural communities. Am. J. Prev. Med. 2000, 18, 235-241. [CrossRef]

11. Bedimo-Rung, A.L.; Mowen, A.J.; Cohen, D.A. The significance of parks to physical activity and public health. Am. J. Prev. Med. 2005, 28, 159-168. [CrossRef]

12. Sallis, J.F.; Bowles, H.R.; Bauman, A.; Ainsworth, B.E.; Bull, F.C.; Craig, C.L.; Sjöström, M.; De Bourdeaudhuij, I.; Lefevre, J.; Matsudo, V.; et al. Neighborhood Environments and Physical Activity Among Adults in 11 Countries. Am. J. Prev. Med. 2009, 36, 484-490. [CrossRef] [PubMed]

13. Sallis, J.F.; Floyd, M.F.; Rodríguez, D.A.; Saelens, B.E. Role of built environments in physical activity, obesity, and cardiovascular disease. Circulation 2012, 125, 729-737. [CrossRef] [PubMed]

14. D'Alessandro, D.; Arletti, S.; Azara, A.; Buffoli, M.; Capasso, L.; Cappuccitti, A.; Casuccio, A.; Cecchini, A.; Costa, G.; De, A.M.M. Strategies for Disease Prevention and Health Promotion in Urban Areas: The Erice 50 Charter. Ann. Ig. Med. Prev. Comunita 2017, 29, 481-493.

15. Capolongo, S.; Rebecchi, A.; Dettori, M.; Appolloni, L.; Azara, A.; Buffoli, M.; Capasso, L.; Casuccio, A.; Oliveri Conti, G.; D'Amico, A.; et al. Healthy Design and Urban Planning Strategies, Actions, and Policy to Achieve Salutogenic Cities. Int. J. Environ. Res. Public Health 2018, 15, 2698. [CrossRef] [PubMed]

16. Saelens, B.E.; Handy, S.L. Built Environment Correlates of Walking: A Review. Med. Sci. Sports Exerc. 2008, 40, S550-S566. [CrossRef]

17. Ewing, R.; Cervero, R. Travel and the Built Environment. J. Am. Plan. Assoc. 2010, 76, 265-294. [CrossRef]

18. Ding, D.; Sallis, J.F.; Kerr, J.; Lee, S.; Rosenberg, D.E. Neighborhood Environment and Physical Activity Among Youth: A Review. Am. J. Prev. Med. 2011, 41, 442-455. [CrossRef]

19. Hickman, R.; Banister, D. Transport, Climate Change and the City; Routledge: London, UK, 2014.

20. Frank, L.D.; Sallis, J.F.; Conway, T.L.; Chapman, J.E.; Saelens, B.E.; Bachman, W. Many pathways from land use to health: Associations between neighborhood walkability and active transportation, body mass index, and air quality. J. Am. Plan. Assoc. 2006, 72, 75-87. [CrossRef]

21. Porter, J.M.; Rathbun, S.L.; Bryan, S.J.; Arseniadis, K.; Caldwell, L.P.; Corso, P.S.; Lee, J.M.; Davis, M. Law Accommodating Nonmotorized Road Users and Pedestrian Fatalities in Florida, 1975 to 2013. Am. J. Public Health 2018, 108, 525-531. [CrossRef]

22. Pucher, J.; Dijkstra, L. Promoting safe walking and cycling to improve public health: Lessons from The Netherlands and Germany. Am. J. Public Health 2003, 93, 1509-1516. [CrossRef]

23. Schneider, R.J. "Complete Streets" Policies and Eliminating Pedestrian Fatalities. Am. J. Public Health 2018, 108, 431-433. [CrossRef] [PubMed]

24. Litman, T. Transportation Cost and Benefit Analysis; Victoria Transport Policy Institute: Victoria, BC, Canada, 2009; p. 31.

25. Boarnet, M.G.; Anderson, C.L.; Day, K.; McMillan, T.; Alfonzo, M. Evaluation of the California Safe Routes to School legislation: Urban form changes and children's active transportation to school. Am. J. Prev. Med. 2005, 28, 134-140. [CrossRef] [PubMed]

26. Brown, B.B.; Werner, C.M.; Amburgey, J.W.; Szalay, C. Walkable route perceptions and physical features: Converging evidence for en route walking experiences. Environ. Behav. 2007, 39, 34-61. [CrossRef]

27. Cao, Y.; Yang, Z.Z.; Zuo, Z.Y. The effect of curb parking on road capacity and traffic safety. Eur. Transp. Res. Rev. 2017, 9, 4. [CrossRef]

28. Guo, Q.; Xu, P.; Pei, X.; Wong, S.C.; Yao, D. The effect of road network patterns on pedestrian safety: A zone-based Bayesian spatial modeling approach. Accid. Anal. Prev. 2017, 99, 114-124. [CrossRef] [PubMed]

29. Leaf, W.A.; Preusser, D.F. Literature Review on Vehicle Speeds and Pedestrian Injuries; US Dept of Transportation: Washington, DC, USA, 1999. 
30. Ewing, R. Fatal and Non-fatal Injuries. Understanding the Relationship Between Public Health and the Built Environment: A Report. LEED-ND Core Committee, 2006. Available online: http:/ /www.activeliving.org/ files/LEEDNDreport.pdf (accessed on 16 February 2019).

31. Ivan, J.N.; Garrick, N.W.; Hanson, G. Designing Roads that Guide Drivers to Choose Safer Speeds; Connecticut Department of Transportation: Rocky Hill, CT, USA, 2009.

32. Gelh, J. Cities for People; Island Press: Washington, DC, USA, 2010.

33. Ewing, R.; Dumbaugh, E. The Built Environment and Traffic Safety: A Review of Empirical Evidence. J. Plan. Lit. 2009, 23, 347-367. [CrossRef]

34. Kadali, B.R.; Vedagiri, P. Evaluation of pedestrian crosswalk level of service (LOS) in perspective of type of land-use. Transp. Res. Part A Policy Pract. 2015, 73, 113-124. [CrossRef]

35. Nasar, J.L.; Holloman, C.; Abdulkarim, D. Street characteristics to encourage children to walk. Transp. Res. Part A Policy Pract. 2015, 72, 62-70. [CrossRef]

36. Elvik, R. The non-linearity of risk and the promotion of environmentally sustainable transport. Accid. Anal. Prev. 2009, 41, 849-855. [CrossRef]

37. Miranda-Moreno, L.F.; Morency, P.; El-Geneidy, A.M. The link between built environment, pedestrian activity and pedestrian-vehicle collision occurrence at signalized intersections. Accid. Anal. Prev. 2011, 43, 1624-1634. [CrossRef]

38. Wier, M.; Weintraub, J.; Humphreys, E.H.; Seto, E.; Bhatia, R. An area-level model of vehicle-pedestrian injury collisions with implications for land use and transportation planning. Accid. Anal. Prev. 2009, 41, 137-145. [CrossRef] [PubMed]

39. Dumbaugh, E.; Li, W. Designing for the safety of pedestrians, cyclists, and motorists in urban environments. J. Am. Plan. Assoc. 2011, 77, 69-88. [CrossRef]

40. Ukkusuri, S.V.; Miranda-Moreno, L.F.; Ramadurai, G.; Isa-Tavarez, J. The role of built environment onnpedestrian crash frequency. Saf. Sci. 2012, 50, 1141-1151. [CrossRef]

41. Clifton, K.J.; Burnier, C.V.; Akar, G. Severity of injury resulting from pedestrian-vehicle crashes: What can we learn from examining the built environment. Transp. Res. D 2009, 14, 425-436. [CrossRef]

42. Moudon, A.V.; Lin, L.; Jiao, J.; Hurvitz, P.; Reeves, P. The risk of pedestrianinjury and fatality in collisions with motor vehicles, a social ecological study of state routes and city streets in King County, Washington. Accid. Anal. Prev. 2011, 43, 11-24. [CrossRef]

43. Hossein Pour, M.; Prasetijo, J.; Yahaya, A.S.; Ghadiri, S.M.R. A Comparative Study of Count Models: Application to Pedestrian-Vehicle Crashes Along Malaysia Federal Roads. Traffic Inj. Prev. 2013, 14, 630-638. [CrossRef] [PubMed]

44. Sun, Z.; Wang, J.; Chen, Y.; Lu, H. Influence Factors on Injury Severity of Traffic Accidents and Differences in Urban Functional Zones: The Empirical Analysis of Beijing. Int. J. Environ. Res. Public Health 2018, 15, 2722. [CrossRef] [PubMed]

45. Blečić, I.; Cecchini, A.; Congiu, T.; Fancello, F.; Fancello, G.; Trunfio, G. Walkability explorer: Application to a case-study. In Lecture Notes in Computer Science (Including Subseries Lecture Notes in Artificial Intelligence and Lecture Notes in Bioinformatics); Springer: Berlin/Heidelberg, Germany, 2015; pp. 758-770. [CrossRef]

46. Blečić, I.; Cecchini, A.; Congiu, T.; Fancello, G.; Trunfio, G.A. Evaluating walkability: A capability-wise planning and design support system. Int. J. Geogr. Inf. Sci. 2015, 29. [CrossRef]

47. Moudon, A.V.; Lee, C. Walking and Biking: An Evaluation of Environmental Audit Instruments. Am. J. Heal. Promot. 2003, 18, 21-37. [CrossRef]

48. Handy, S.L.; Boarnet, M.G.; Ewing, R.; Killingsworth, R.E. How the built environment affects physical activity: Views from urban planning. Am. J. Prev. Med. 2002, 23, 64-73. [CrossRef]

49. Ewing, R.; Handy, S. Measuring the Unmeasurable: Urban Design Qualities Related to Walkability. J. Urban Des. 2009, 14, 65-84. [CrossRef]

50. Jacobs, J. The Death and Life of Great American Cities, 1st ed.; Vintage Books: York, NY, USA, 1961.

51. Okabe, A.; Satoh, T.; Sugihara, K. A kernel density estimation method for networks, its computational method and a GIS-based tool. Int. J. Geogr. Inf. Sci. 2009, 23, 7-32. [CrossRef]

52. Okabe, A.; Sugihara, K. Spatial Analysis along Networks: Statistical and Computational Methods; John Wiley \& Sons: York, NY, USA, 2012.

53. Xie, Z.; Yan, J. Kernel Density Estimation of traffic accidents in a network space. Comput. Environ. Urban Syst. 2008, 32, 396-406. [CrossRef] 
54. Schlossberg, M. From TIGER to Audit Instruments: Measuring Neighborhood Walkability with Street Data Based on Geographic Information Systems. Transp. Res. Rec. J. Transp. Res. Board 2006, 1982, 48-56. [CrossRef]

55. Weinstein Agrawal, A.; Schlossberg, M.; Irvin, K. How Far, by Which Route and Why? A Spatial Analysis of Pedestrian Preference. J. Urban Des. 2008, 13, 81-98. [CrossRef]

56. Yang, Y.; Diez-Roux, A.V. Walking Distance by Trip Purpose and Population Subgroups. Am. J. Prev. Med. 2012, 43, 11-19. [CrossRef] [PubMed]

57. Saelens, B.E.; Sallis, J.F.; Frank, L.D. Environmental correlates of walking and cycling: Findings from the transportation, urban design, and planning literatures. Ann. Behav. Med. 2003, 25, 80-91. [CrossRef]

58. World Health Organization. Towards More Physical Activity in Cities Transforming Public Spaces to Promote Physical Activity-A Key Contributor to Achieving the Sustainable Development Goals in Europe. Available online: http://www.euro.who.int/_data/assets/pdf_file/0018/353043/2017_WHO_Report_ FINAL_WEB.pdf?ua=1 (accessed on 16 February 2019).

59. Kröyer, H.R.G. Is $30 \mathrm{~km} / \mathrm{h}$ a 'safe' speed? Injury severity of pedestrians struck by a vehicle and the relation to travel speed and age. Iatss Res. 2015, 39, 42-50. [CrossRef]

60. Dai, D.; Taquechel, E.; Steward, J.; Strasser, S. The impact of built environment on pedestrian crashes and the identification of crash clusters on an urban university campus. West. J. Emerg. Med. 2010, 11, 294.

61. Swift, P.; Painter, D.; Goldstein, M. Residential Street Typology and Injury Accident Frequency. Available online: https://www.cnu.org/sites/default/files/swift_painter_goldstein_study.pdf (accessed on 16 February 2019).

62. Gårder, P.E. The impact of speed and other variables on pedestrian safety in Maine. Accid. Anal. Prev. 2004, 36, 533-542. [CrossRef]

63. Schuurman, N.; Cinnamon, J.; Crooks, V.A.; Hameed, S.M. Pedestrian injury and the built environment: An environmental scan of hotspots. BMC Public Health 2009, 9, 233. [CrossRef] [PubMed]

64. Stoker, P.; Garfinkel-Castro, A.; Khayesi, M.; Odero, W.; Mwangi, M.N.; Peden, M.; Ewing, R. Pedestrian Safety and the Built Environment: A Review of the Risk Factors. J. Plan. Lit. 2015, 30, 377-392. [CrossRef]

65. NACTO. NACTO Urban Street Design Guide; National Association of City Transportation Officials: New York, NY, USA, 2012. [CrossRef]

66. Martin, A. Factors Influencing Pedestrian Safety: A Literature Review; Wokingham: Berks, UK, 2006.

67. Agran, P.F.; Winn, D.G.; Anderson, C.L.; Tran, C.; Del Valle, C.P. The role of physical and traffic environment in child pedestrian injuries. Pediatrics 1996, 98, 1096-1103.

68. Retting, R.A.; Ferguson, S.A.; McCartt, A.T. Review of Evidence-Based Traffic Engineering Measures Designed to Reduce Pedestrian-Motor Vehicle Crashes. Am. J. Public Health 2003, 93, 1456-1463. [CrossRef] [PubMed]

69. Lydon, M.; Garcia, A. Tactical Urbanism. Short-term Action for Long-Term Change; Island Press: Washington, DC, USA, 2015.

70. Open Streets Project. Available online: http:// openstreetsproject.org/ (accessed on 9 August 2018).

71. Schlossberg, M.; Rowell, J.; Amos, D.; Sanford, K. Rethinking Streets: An Evidence-Based Guide to 25 Complete Street Transformations; University of Oregon: Eugene, Oregon, USA, 2013.

72. Transportation Alternatives. Traffic's Human Toll. A Study of the Impacts of Vehicular Traffic on New York City Residents. New York. 2006. Available online: www.transalt.org/newsroom/reports (accessed on 16 July 2018).

73. Finch, C.F.; Hayen, A. Governmental health agencies need to assume leadership in injury prevention. Inj. Prev. 2006. [CrossRef]

74. Belin, M.Å.; Tillgren, P.; Vedung, E. Vision Zero-A road safety policy innovation. Int. J. Inj. Contr. Saf. Promot. 2012. [CrossRef]

75. World Health Organization. Global Status Report on Road Safety: Supporting a Decade of Action. Available online: http:/ / www.who.int/violence_injury_prevention/road_safety_status/2013/en/index. html (accessed on 16 February 2019).

76. Nasar, J.L.; Troyer, D. Pedestrian injuries due to mobile phone use in public places. Accid. Anal. Prev. 2013, 57, 91-95. [CrossRef] [PubMed] 
77. Byington, K.W.; Schwebel, D.C. Effects of mobile Internet use on college student pedestrian injury risk. Accid. Anal. Prev. 2013, 51, 78-83. [CrossRef]

78. Toran Pour, A.; Moridpour, S.; Tay, R. Influence of pedestrian age and gender on spatial and temporal distribution of pedestrian crashes. Traffic Inj. Prev. 2018, 19, 81-87. [CrossRef] [PubMed] 